\title{
The serum homocysteine level in patients with acute ischemic stroke (AIS) after thrombolysis and its relationship with clinical outcomes
}

\author{
Ling-Cong ${ }^{2}$ \\ Hong-Zhao ${ }^{2}$ \\ Yu- Wang ${ }^{2}$ \\ $Y u-L i^{2}$ \\ (iD) Xin-Sui ${ }^{1}$
}

1. The Second Internal Medicine-Neurology, Jilin Electric Power Hospital, Nanguan, Changchun, China; 2. The Third Affiliated Hospital of Qiqihaer Medical University, Qiqihar, Heilongjiang, China

http://dx.doi.org/10.1590/1806-9282.64.05.438

\section{SUMMARY}

OBJECTIVE: The present study aims to investigate whether hyperhomocysteinemia (HHcy) affects the outcomes of the thrombolytic treatment for patients with AIS.

METHODS: A sample of 120 AIS patients were recruited and grouped according to their serum homocysteine (Hcy) levels. The National Institute of Health Stroke Scale (NIHSS) was obtained before treatment and 7 days after it to evaluate neurological outcomes; modified Rankin Scale (mRS) was obtained 12 weeks later to assess functional outcomes. Receiver operating characteristic curve (ROC) was used to demonstrate the relationship between serum Hcy level and the outcomes after $t$ PA treatment.

RESULTS: The serum Hcy level of 120 patients was of $27.57 \pm 20.17 \mu \mathrm{mol} / \mathrm{L}$. The NIHSS scores of the patients in the low Hcy level group were remarkably lower compared to those in the high-level group ( $p<0.05)$, after 7 days of treatment. In addition, the $m R S$ scores of the patients in the low Hcy level group, after 12 weeks, were remarkably lower compared to those in the high-level group $(p<0.01)$. ROC demonstrated that the serum Hcy level is related to the clinical outcomes of thrombolytic treatment with moderate specificity (80.3\%) and sensitivity (58.2\%).

CONCLUSION: In conclusion, higher serum Hcy levels can indicate poorer clinical outcomes of thrombolytic treatment in patients with AIS.

KEYWORDS: Homocysteine. Stroke. Thrombolytic Therapy.

Nowadays in China, AIS is one of the leading causes of disability and death. It brings tremendous financial burden to patients' families '. Intravenous thrombolysis (IVT) and alteplase (t-PA) has been widely used in AIS patients within 4.5 hours after the onset ${ }^{2-4}$. However, its possible complications i.e. symptomatic intracerebral hemorrhage (sICH) require appropriate precautions. To the best of our knowledge, reliable methods and indexes to predict
sICH and evaluate treatment outcomes of IVT still lack in clinical practice. Therefore, an accurate predictor with reasonable sensitivity and specificity is needed.

Previous investigations have indicated that hyperhomocysteinemia (HHcy) is related to a higher risk of AIS and poor prognosis of patients with AIS, with a possible underlying mechanism in which increased serum homocysteine (Hcy) may result in endothe- 
lial dysfunction, neurotoxicity, and upregulation of prothrombotic factors ${ }^{5-7}$. However, the possibility to also use HHcy to predict clinical outcomes after tPA treatment has not been comprehensively studied. The present study aims to retrospectively research the possible relationship between HHcy and clinical outcomes of tPA for patients with AIS.

\section{MATERIAL AND METHODOLOGY}

Ethical approvals were obtained from the Ethics Review Committee of the West China Hospital (Chengdu, Sichuan, China). We collected and analyzed data from consecutive AIS patients treated in the Department of Neurology of the West China Hospital between January of 2011 and December of 2014. All patients provided written informed consent.

Criteria for inclusion: (1) Age $\geq 18$ years; (2) Diagnosis of AIS validated by head CT scanning; (3) Beginning of tPA treatment within $4.5 \mathrm{~h}$ after the onset.

Criteria for exclusion: (1) Prior stroke within 12 weeks; (2) History of intracranial hemorrhage; (3) Recent intraspinal or intracranial surgery; (4) Active internal bleeding; (5) Hypertension (systolic BP $>185 \mathrm{mmHg}$ or diastolic BP $>110 \mathrm{mmHg}$ ); (6) Blood glucose concentration $<2.7 \mathrm{mmol} /$; ; (7) Multiple lobar infarction demonstrated by head CT; (8) Unwillingness to participate.

Upon admission, a head CT was performed on all patients, and clinical characteristics including sex, age, history of smoking and alcohol consumption, systolic and diastolic BP, hypertension, diabetes mellitus, coronary atherosclerotic cardiovascular disease, previous stroke, atrial fibrillation, time of thrombolysis, and stroke subtypes were gathered. The NIHSS scores were evaluated upon admission and 7 days after tPA treatment in order to assess the severity of AIS and the outcomes of tPA treatment. The mRS was performed after 12 weeks to evaluate the long-term outcomes. In addition, laboratory tests including platelet count, hemoglobin level, fasting blood-glucose and uric acid level, fibrinogen level, serum homocysteine level, and serum lipid profile were conducted on admission.

\section{TREATMENT}

The patients were given intravenous alteplase $(0.9 \mathrm{mg} / \mathrm{kg}$, maximum 90mg, Boehringer-Ingelheim Pharmaceuticals, Germany) within $4.5 \mathrm{~h}$ of onset
(10\% in pellet within $1 \mathrm{~min}$, remaining $90 \%$ was intravenously infused within $1 \mathrm{~h})^{2-4}$.

\section{CLINICAL OUTCOMES}

The NIHSS score was performed on admission and 7 days after tPA treatment to assess the severity and progression of AIS. All patients underwent head CT or MRI scan within 1 day after the tPA treatment. The secondary endpoint was Symptomatic Intracerebral Hemorrhage (sICH). The sICH was defined as a detectable hemorrhage and parenchymal hematoma on the head CT or MRI with a neurological deterioration (NIHSS score $\geq 4$ ) [8]. All patients were reevaluated at 12 weeks after tPA treatment using the mRS score.

\section{STATISTICAL ANALYSIS}

IBM SPSS version 17.0 was used to conduct statistical analysis. A t-test was performed to compare the continuous variables. The Pearson chi-square test and Fisher exact test were performed to compare the categorical variables. Possible predictors of poor prognosis were evaluated by using multiple logistic regression analysis. The ability of serum Hcy level to predict patient prognosis was investigated by calculating the area under the receiver operating characteristic curve (AUC).

\section{RESULTS AND ANALYSIS}

A sample of 120 patients which included 87 males and 33 females with mean age of $65.7 \pm 12.7$ years were recruited for this study. The serum Hcy level was $27.57 \pm 20.17 \mu \mathrm{mol} / \mathrm{L}$. The serum Hcy levels were divided into quartiles of $1,2,3$, and 4 with ranges of 2.26 to $11.50 \mu \mathrm{mol} / \mathrm{L}, 11.50$ to $17.70 \mu \mathrm{mol} / \mathrm{L}, 17.70$ to $23.85 \mu \mathrm{mol} / \mathrm{L}$, and 23.85 to $138.90 \mu \mathrm{mol} / \mathrm{L}$, respectively. The serum Hcy median level was $17.70 \mu \mathrm{mol} / \mathrm{L}$. Patients with $\mathrm{Hcy}<17.70 \mu \mathrm{mol} / \mathrm{L}$ were assigned to the low concentration group and the other patients were assigned to the high concentration group.

Different clinical characters of patients in the two groups are presented in Table 1. There were more male patients in the high concentration group $(P<0.01)$. Additionally, the univariate analysis demonstrated that smoking, alcohol consumption, uric acid level, hemoglobin level, and diabetes mellitus were related to a higher concentration of Hcy $(P<0.05)$. 
TABLE 1. CLINICAL CHARACTERS AND OUTCOMES OF PATIENTS IN LOW AND HIGH HCY CONCENTRATION GROUPS.

\begin{tabular}{|c|c|c|c|}
\hline & \multicolumn{2}{|l|}{ Hcy level } & \multirow[t]{2}{*}{ P-value } \\
\hline & $\begin{array}{l}\text { Low concen- } \\
\text { tration }(n=63)\end{array}$ & $\begin{array}{l}\text { High concen- } \\
\text { tration }(n=57)\end{array}$ & \\
\hline Age, y & $65.67 \pm 11.50$ & $62.55 \pm 15.02$ & 0.556 \\
\hline Male $[n(\%)]$ & $44(69.84)$ & $43(75.44)$ & $<0.001$ \\
\hline $\begin{array}{l}\text { Alcohol consumption } \\
{[\mathrm{n}(\%)]}\end{array}$ & $17(26.98)$ & $14(24.56)$ & 0.017 \\
\hline $\begin{array}{l}\text { Current smoking } \\
\text { status }[\mathrm{n}(\%)]\end{array}$ & $44(69.84)$ & $31(54.40)$ & $<0.001$ \\
\hline $\begin{array}{l}\text { Hypertension } \\
{[\mathrm{n}(\%)]}\end{array}$ & $33(52.38)$ & $37(64.91)$ & 0.577 \\
\hline $\begin{array}{l}\text { Diabetes mellitus } \\
{[\mathrm{n}(\%)]}\end{array}$ & $23(36.50)$ & $9(15.79)$ & 0.015 \\
\hline $\begin{array}{l}\text { Coronary atheroscle- } \\
\text { rotic cardiovascular } \\
\text { disease }[\mathrm{n}(\%)]\end{array}$ & $27(42.86)$ & $20(35.09)$ & 0.75 \\
\hline $\begin{array}{l}\text { Atrial fibrillation } \\
{[n(\%)]}\end{array}$ & $6(9.52)$ & $9(15.79)$ & 0.157 \\
\hline $\begin{array}{l}\text { Previous stroke } \\
{[\mathrm{n}(\%)]}\end{array}$ & $13(20.63)$ & $11(19.30)$ & 0.205 \\
\hline Hemoglobin (g/L) & $135.45 \pm 15.25$ & $141.55 \pm 19.41$ & 0.05 \\
\hline $\begin{array}{l}\text { Platelet count } \\
\left(\times 10^{9} / \mathrm{L}\right)\end{array}$ & $212.27 \pm 61.75$ & $225.95 \pm 73.55$ & 0.25 \\
\hline Fibrinogen level (g/L) & $3.00 \pm 0.75$ & $3.01 \pm 0.95$ & 0.997 \\
\hline Uric acid $(\mu \mathrm{mol} / \mathrm{L})$ & $259.22 \pm 82.57$ & $302.67 \pm 97.77$ & $<0.001$ \\
\hline $\begin{array}{l}\text { Blood glucose level } \\
(\mathrm{mmol} / \mathrm{L})\end{array}$ & $6.35 \pm 2.27$ & $6.07 \pm 2.77$ & 0.487 \\
\hline Triglyceride (mmol/L) & $1.55 \pm 1.05$ & $1.77 \pm 1.10$ & 0.577 \\
\hline $\begin{array}{l}\text { Low-density lipopro- } \\
\text { tein }(\mathrm{mmol} / \mathrm{L})\end{array}$ & $2.77 \pm 0.05$ & $2.87 \pm 1.17$ & 0.557 \\
\hline $\begin{array}{l}\text { High-density lipopro- } \\
\text { tein }(\mathrm{mmol} / \mathrm{L})\end{array}$ & $2.77 \pm 0.87$ & $2.87 \pm 1.07$ & 0.557 \\
\hline $\begin{array}{l}\text { Total cholesterol } \\
(\mathrm{mmol} / \mathrm{L})\end{array}$ & $2.75 \pm 0.87$ & $2.80 \pm 1.17$ & 0.507 \\
\hline $\mathrm{slCH}(\%)$ & $13(20.63)$ & $44(77.19)$ & 0.017 \\
\hline NIHSS on admission & $7.97 \pm 2.77$ & $8.09 \pm 3.02$ & 0.55 \\
\hline $\begin{array}{l}\text { NIHSS 7-day after } \\
\text { treatment }\end{array}$ & $4.57 \pm 5.57$ & $6.87 \pm 7.70$ & 0.007 \\
\hline $\begin{array}{l}\text { mRS 12-week after } \\
\text { treatment }\end{array}$ & $1.77 \pm 1.50$ & $2.37 \pm 1.70$ & 0.007 \\
\hline
\end{tabular}

No significant difference was observed between the 2 groups regarding NIHSS scores obtained on admission. However, the scores of the low concentration group were significantly lower than those of the high concentration group, 7 days after tPA treatment $(\mathrm{P}<0.05)$. The sICH was found in $57(47.50 \%)$ patients within $24 \mathrm{~h}$ after initiation of tPA. There were significantly more patients with sICH in the high concentration group $(\mathrm{P}<0.05)$. In addition, mRS scores indicated poor prognosis after 12 weeks $(\mathrm{P}<0.01)$.

Univariate analysis demonstrated that Hcy level, NIHSS score on admission, uric acid level, and dia-
TABLE 2. MODIFIED RANKIN SCALE AND ODDS RATIO WITH RESPECT TO HCY QUARTILES.

\begin{tabular}{l|l|l|l} 
& OR & $95 \% \mathrm{Cl}$ & $\mathrm{P}$-value \\
\hline Q1 & $\mathrm{nr}$ & $\mathrm{nr}$ & $\mathrm{nr}$ \\
\hline Q2 & 1.83 & $0.49-6.81$ & 0.370 \\
\hline Q4 & 2.29 & $0.62-8.43$ & 0.241 \\
\hline Male & 13.75 & $3.57-51.77$ & $<0.001$ \\
\hline Age & 0.711 & $0.181-2.80$ & 0.626 \\
\hline $\begin{array}{l}\text { Alcohol consump- } \\
\text { tion }\end{array}$ & 1.65 & $0.966-1.04$ & 0.965 \\
\hline $\begin{array}{l}\text { Current smoking } \\
\text { status }\end{array}$ & 0.468 & $0.138-1.59$ & 0.415 \\
\hline Diabetes mellitus & 0.981 & $0.324-2.97$ & 0.223 \\
\hline Hemoglobin & 1.00 & $0.978-1.03$ & 0.974 \\
\hline Uric acid & 0.999 & $0.994-1.00$ & 0.771 \\
\hline $\begin{array}{l}\text { NIHSS on admis- } \\
\text { sion }\end{array}$ & 1.61 & $1.38-1.86$ & 0.598 \\
\hline
\end{tabular}

nr: not relevant

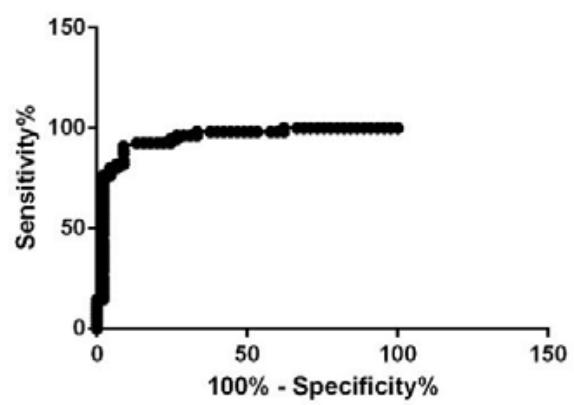

FIG.1. The ability of serum Hcy level to predict prognosis of AIS was assessed by conducting ROC analysis.

betes mellitus were related to the prognosis. That NIHSS score on admission and Hcy level were independent predictors of poor prognosis $(\mathrm{P}<0.001)$ was demonstrated by multiple logistic regression analysis (Table 2). The fourth quartile (23.85 to $138.90 \mu \mathrm{mol} / \mathrm{L})$ of the Hcy level was considered to be an independent predictor of poor prognosis (OR 13.75, 95\% CI 3.57-51.77, $\mathrm{P}<0.001)$. The risk of poor prognosis gets higher as Hcy level increases, as illustrated in Fig.1. ROC analysis showed an AUC value of 0.685 (95\% CI $0.603-0.768$ ) and a cut-off value of $17.75 \mu \mathrm{mol} / \mathrm{L}$ with a sensitivity of $58.2 \%$ and specificity of $80.3 \%$. 


\section{DISCUSSION}

The IVT with t-PA has been widely used in AIS patients within 4.5 hours after the onset ${ }^{2-4}$. However, sICH is a fatal complication of tPA and limits its clinical application. Therefore, it is useful to discover an index that can predict the risk of sICH after tPA treatment. Previous studies have reported that serum Hcy level might be able to predict the occurrence of AIS ${ }^{5-7}$. Zhou et al. ${ }^{9}$ have discovered that higher serum Hcy level was related to a larger volume of hematoma of AIS patients, with the possible underlying mechanism of disruption of the cerebral vessel wall integrity caused by elevated Hcy ${ }^{10-12}$. Our study aimed to research the potential relationship between serum Hcy level and sICH.

This study has demonstrated that $17.7 \mu \mathrm{mol} / \mathrm{L}$ is the cut-off value to determine whether the serum Hcy level of a patient is higher than average. Patients with high Hcy concentrations tended to have worse clinical outcomes after tPA treatment, compared to patients with low concentrations. This was demonstrated by NIHSS and mRS scores after 7 days and 12 weeks. The results suggested that high Hcy levels predicted poor prognosis after tPA treatment.

Although some recent studies have demonstrated the relationship between high Hcy level and elevated risk of AIS, the predicative value of patients' Hcy level following tPA treatment has not been studied comprehensively. Several studies have shown that high Hcy level is an independent risk factor for both long and short-term poor prognosis, which is consistent with our results ${ }^{5-7,13,14}$. Toole et al. ${ }^{15}$ have shown that the stroke risk decreases by $10 \%$ as the serum Hcy level decreases by $3 \mu \mathrm{mol} / \mathrm{L}$. The cut-off value was determined to be $17.75 \mu \mathrm{mol} / \mathrm{L}$ based on the ROC model. It was close to the cutoff value $(17.64 \mu \mathrm{mol} / \mathrm{L})$ reported from Yan et al. [16]. Therefore, we have shown that the cut-off value of $17.75 \mu \mathrm{mol} / \mathrm{L}$ is a reliable predictor of poor prognosis in patients with AIS following tPA treatment. As far as we know, this was the first retrospective study to report the relationship between high Hcy level and poor prognosis after tPA treatment.

Several limitations exist in the present study. First of all, this is a retrospective analysis with relatively small sample size which did not include AIS patients without thrombolytic treatment as a control group. Therefore, a multicenter randomized controlled study should be conducted in the future to validate and confirm the results of the present study. Secondly, multiple factors affect the serum Hcy lev$\mathrm{el}$, including genetic background, general nutrition, health, and various comorbidities such as nephropathy, diabetes mellitus, etc. ${ }^{17}$. Therefore, it was impossible to eliminate all the confounding factors during the follow-up, which inevitably affected the results.

In conclusion, the present study suggested that increased serum Hcy level was an independent risk predictor of sICH and poor prognosis in AIS patients who underwent tPA treatment. The cut-off value of $17.75 \mu \mathrm{mol} / \mathrm{L}$ provided a valuable reference point for Chinese patients.

\section{RESUMO}

OBJETIVO: O presente estudo tem por objetivo investigar se a hiperhomocisteinemia (HHcy) afeta os resultados do tratamento trombolítico em pacientes com AVCl agudo.

METODOLOGIA: Uma amostra de 120 pacientes AVCl agudo foi recrutada e agrupada de acordo com os níveis séricos de homocisteína (Hcy). Uma avaliação nos padrões do National Institute of Health Stroke Scale (NIHSS) foi obtida antes do tratamento e 7 dias após ele para avaliar desfechos neurológicos e a escala de Rankin modificada foi utilizada 12 semanas depois para avaliar os desfechos funcionais. A curva ROC (Receiver Operating Caracteristic) foi utilizada para demonstrar a relação entre os níveis séricos de Hcy e os desfechos após tratamento com t-PA.

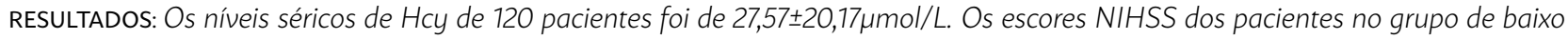
nível de Hcy foram notavelmente mais baixos em comparação àqueles do grupo de nível mais alto ( $p<0,05)$, após 7 dias de tratamento. Além disso, os escores mRS dos pacientes no grupo de baixo nível de Hcy, após 12 semanas, foram consideravelmente mais baixos em comparação com os do grupo de alto nível $(p<0,01)$. A curva ROC demonstrou que o nível sérico de Hcy tem relação com os desfechos clínicos do tratamento trombolítico com especificidade moderada (80,3\%) e sensibilidade (58,2\%).

CONCLUSÃo: Podemos concluir então que níveis séricos mais altos de Hcy podem prever desfechos clínicos piores para o tratamento trombolítico em pacientes com AVCl agudo.

PALAVRAS-CHAVE: Homocisteína. Derrame. Terapia trombolítica. 


\section{REFERENCES}

1. Kim AS, Johnston SC. Global variation in the relative burden of stroke and ischemic heart disease. Circulation. 2011;124(3):314-23.

2. Valdés Hernández MC, Piper RJ, Bastin ME, Royle NA, Maniega SM, Aribisala BS, et al. Morphologic, distributional, volumetric, and intensity characterization of periventricular hyperintensities. AJNR Am | Neuroradiol. 2014;35(1):55-62.

3. Hacke W, Kaste M, Bluhmki E, Brozman M, Dávalos A, Guidetti D, et al; ECASS Investigators. Thrombolysis with alteplase 3 to 4.5 hours after acute ischemic stroke. N Engl J Med. 2008;359(13):1317-29.

4. Lai SM, Alter M, Friday G, Sobel E. A multifactorial analysis of risk factors for recurrence of ischemic stroke. Stroke. 1994;25(5):958-62.

5. Erten-Lyons D, Woltjer R, Kaye J, Mattek N, Dodge HH, Green S, et al. Neuropathologic basis of white matter hyperintensity accumulation with advanced age. Neurology. 2013;81(11):977-83.

6. Kwon HM, Lee YS, Bae HJ, Kang DW. Homocysteine as a predictor of early neurological deterioration in acute ischemic stroke. Stroke. 2014;45(3):871-3.

7. Homocysteine Studies Collaboration. Homocysteine and risk of ischemic heart disease and stroke: a meta-analysis. JAMA. 2002;288(16):2015-22.

8. Vermeer SE, van Dijk EJ, Koudstaal PJ, Oudkerk M, Hofman A, Clarke R, et al. Homocysteine, silent brain infarcts, and white matter lesions: The Rotterdam Scan Study. Ann Neurol. 2002;51(3):285-9.

9. Zhou F, Chen B, Chen C, Huang J, Chen S, Guo F, et al. Elevated homocysteine levels contribute to larger hematoma volume in patients with intracerebral hemorrhage. I Stroke Cerebrovasc Dis. 2015;24(4):784-8.

10. Welch GN, Loscalzo J. Homocysteine and atherothrombosis. N Engl J
Med. 1998:338(15):1042-50.

11. Hooshmand B, Polvikoski T, Kivipelto M, Tanskanen M, Myllykangas L, Erkinjuntti T, et al. Plasma homocysteine, Alzheimer and cerebrovascular pathology: a population-based autopsy study. Brain. 2013;136(Pt 9):270716.

12. Ribo M, Montaner J, Molina CA, Arenillas JF, Santamarina E, Quintana M, et al. Admission fibrinolytic profile is associated with symptomatic hemorrhagic transformation in stroke patients treated with tissue plasminogen activator. Stroke. 2004;35(9):2123-7.

13. Spence JD. B vitamin therapy for homocysteine: renal function and vitamin B12 determine cardiovascular outcomes. Clin Chem Lab Med. 2013;51(3):633-7.

14. Chou PS, Chen $\mathrm{CH}$, Wu MN, Lin YH, Lai CL, Lin RT, et al. Determinants of cerebral white matter changes in patients with stroke. Intern Med J. 2015;45(4):390-5.

15. Toole JF, Malinow MR, Chambless LE, Spence JD, Pettigrew LC, Howard $V$ J, et al. Lowering homocysteine in patients with ischemic stroke to prevent recurrent stroke, myocardial infarction, and death: the Vitamin Intervention for Stroke Prevention (VISP) randomized controlled trial. JAMA. 2004;291(5):565-75.

16. Bostom AG, Selhub J, Jacques PF, Rosenberg IH. Power Shortage: clinical trials testing the "homocysteine hypothesis" against a background of folic acid-fortified cereal grain flour. Ann Intern Med. 2001;135:133-137.

17. Raz N, Yang Y, Dahle CL, Land S. Volume of white matter hyperintensities in healthy adults: contribution of age, vascular risk factors, and inflammation-related genetic variants. Biochim Biophys Acta. 2012;1822(3):361-9. 